\title{
Hjerteinfarkt, mettet fett og kolesterol
}

\author{
Det går for tiden en diskusjon i Tidsskriftets spalter om sammenhengen mellom mettet fett i kostholdet \\ og dødelighet av hjerteinfarkt. Det er blitt hevdet at statiner ikke reduserer dødeligheten, og at det ikke er \\ sammenheng mellom kolesterol og hjertedødelighet. Begge påstandene er feil.
}

Paal Røiri skriver at kolesterolnivået i blodet ikke har noen sammenheng med dødeligheten av hjerte- og karsykdommer, og at årsaken til de mange mislykkede studiene med statiner er at kolesterolhypotesen ikke holder (1). Han skriver at statin reduserte den absolutte dødeligheten med 3,3\% i en studie i løpet av en femårsperiode, en ubetydelig effekt mener han (2). I 4S-studien, som han sikter til, var det 256 personer som døde i placebogruppen og 182 i statingruppen. Altså ble 74 liv spart. Om de som døde synes dette var ubetydelig, får vi aldri svar på. Gjennomsnittsalderen var 58 år for menn og 60 for kvinner ved studiestart. Videre var det ikke bare 74 liv som ble forlenget, men også 191 færre tilfeller av alvorlig hjertesykdom med derav følgende plager i statingruppen. Vi kan konkludere med at når 2223 personer bruker statiner i 5,4 år, er dette forventet gevinst.

Også når det gjelder kost og livsstil mener Røiri at «kolesterolhypotesen ikke holder». Røiri sår tvil om Paul Lerens koststudie (3) og hevder at reduksjonen ikke var statistisk signifikant. Leren randomiserte 412 menn i to grupper. Halvparten fikk kostintervensjon med råd om å erstatte mettet fett med umettet fett. Slike råd ble ikke gitt til kontrollgruppen. Etter nøyaktig fem år hadde gjennomsnittlig totalkolesterol falt med $17,6 \%$ i gruppen med kostintervensjon og 3,7\% i kontrollgruppen. Antall alvorlige hjerte- og karhendelser etter fem år var 80 $i$ gruppen som fikk kostintervensjon mot $120 \mathrm{i}$ gruppen som ikke hadde fått kostintervensjon. I intervensjonsgruppen døde 10 personer av hjerteinfarkt mot 23 i kontrollgruppen. Forskjellen var statistisk signifikant med $\mathrm{p}=0,029$.

\section{Forskning på kosthold}

I studier om kostintervensjon kan man aldri levere bevis med samme styrke som i en medikamentstudie som 4S. Årsakene er mange, men placebo og prinsippet med dobbeltblinding er en utfordring i kostintervensjoner. Man kan jo ikke gi en placebofisk eller placebofrukt. Videre inneholder mat energi - i motsetning til statiner - derfor vil det à spise mer av noe ofte bety at man spiser mindre av noe annet. Da må man spørre seg om en eventuell effekt kom av at man spiste mer fisk - eller mindre kjøtt? Resultater av koststudier er altså beheftet med større usikkerhet enn studier av typen 4S, et faktum som utvilsomt bidrar til usikkerhet og stadig nye avisoverskrifter når det gjelder hva som er sunt. Store bakenforliggende økonomiske interesser knyttet til produksjon og salg av ulik mat kan også utnytte rom for tolkning i sin agenda. Vi må derfor erkjenne svakheten i koststudier jamfør medikamentstudier for å forstå debatten. Offisielle kostråd utarbeides derfor av vitenskapelige

\section{«Man kan jo ikke gi en placebofisk eller placebofrukt»}

komiteer som er oppnevnt av offentlige myndigheter. Komiteene gjør en systematisk oppsummering av all tilgjengelig kunnskap. I arbeidet med de nye nordiske kostrådene (NNR) var mer enn 100 vitenskapelige eksperter involvert (4). Av disse rådene fremgår det at risikoen for kardiovaskulær sykdom reduseres ved å erstatte mettet fett med flerumettet fett, og beviskraften er klassifisert i den høyeste kategorien («convincing evidence»).

I sin klassiske studie på middelaldrende menn i Oslo fant Hjermann og medarbeidere $13 \%$ reduksjon i totalkolesterol og $47 \%$ reduksjon i insidens av hjerteinfarkt og plutselig død (5). Intervensjonsgruppen reduserte kraftig inntaket av mettet fett. Det var også $8 \%$ flere som sluttet å røyke, men mange hadde begynt igjen tre år etter at studien var avsluttet (6). Det var derfor oppsiktsvekkende å konstatere en livslang effekt ved 40 års oppfølging av denne randomiserte kontrollerte intervensjonsstudien (7).

\section{Riktig informasjon til pasientene}

Å påstå at høyt serumkolesterol er uten betydning kan kanskje virke uskyldig, men til sammenligning er det som å informere om at sikkerhetsbelte er tull og tøys. Å gi informasjon om at det for de fleste er enkelt å beskytte seg mot sykdom er viktig. Fordi hjerte- og karsykdom er den sykdomsgruppen som tar flest liv, er det derfor av stor samfunnsmessig betydning å få målt kolesterol, blodtrykk og glukose minst én gang slik at organskade kan forebygges.
Jeg takker ph.d.-stipendiat Karianne Svendsen for kritisk gjennomlesning og kommentarer til manuskriptet.

\section{Kjetil Retterstøl}

kjetil.retterstol@medisin.uio.no

Kjetil Retterstøl (f. 1962) er spesialist i medisinsk biokjemi og professor ved Avdeling for ernæringsvitenskap, Universitetet i Oslo, og overlege ved Lipidklinikken, Oslo universitetssykehus. Han leder forskningsgruppen Aterosklerose og lipidologi og Senter for klinisk ernæring, Oslo universitetssykehus og Universitetet i Oslo. I tillegg er han nestleder i Nasjonalt råd for ernæring.

Forfatter har fylt ut ICMJE-skjemaet og oppgir følgende interessekonflikter: Han har mottatt honorar fra Sanofi, Mills DA, Amgen, MSD, Chiesi, Takeda, Norsk cardiologisk selskap, Den norske legeforening, Norges forskningsråd.

\section{Litteratur}

1. Røiri P. Reduksjon av hjertedød skyldes ikke statiner. Tidsskr Nor Legeforen 2016; 136: 895.

2. Røiri P. Re: Hjerteinfarkt før og nå - et 50 års perspektiv. Tidsskr Nor Legeforen 2016; publisert først på nett.

3. Leren P. The effect of plasma cholesterol lowering diet in male survivors of myocardial infarction. A controlled clinical trial. Acta Med Scand Suppl 1966 ; 466 : $1-92$.

4. Nordic Council of Ministers. Nordic Nutrition Recommendations 2012: Integrating nutrition and physcial activity. Nord 2014: 002. https://norden. org/en/theme/nordic-nutrition-recommendation/ nordic-nutrition-recommendations-2012 (1.7.2016)

5. Hjermann I, Velve Byre K, Holme I et al. Effect of diet and smoking intervention on the incidence of coronary heart disease. Report from the Oslo Study Group of a randomised trial in healthy men Lancet 1981; 2: 1303-10.

6. Hjermann I, Holme I, Leren P. Oslo study diet and antismoking trial. Results after 102 months. Am J Med 1986; 80 (2A): 7-11.

7. Holme I, Retterstøl K, Norum KR et al. Lifelong benefits on myocardial infarction mortality: 40-year follow-up of the randomized Oslo diet and antismoking study. J Intern Med. E-publisert 16. februar 2016.

Mottatt 29.6. 2016 og godkjent 1.7. 2016. Redaktør: Ketil Slagstad.

Publisert først på nett. 